\title{
China's Economic Growth and Financial Development after Reform and Opening-up
}

\author{
Yan Zhang \\ Department of International Studies, Faculty of International Studies, Meiji Gakuin University, Japan
}

Received August 16, 2020; Revised October 5, 2020; Accepted October 19, 2020

\section{Cite This Paper in the following Citation Styles}

(a): [1] Yan Zhang, "China's Economic Growth and Financial Development after Reform and Opening-up, "Advances in Economics and Business, Vol. 8, No. 6, pp. 321 - 332, 2020. DOI: 10.13189/aeb.2020.080602.

(b): Yan Zhang (2020). China's Economic Growth and Financial Development after Reform and Opening-up. Advances in Economics and Business, 8(6), 321 - 332. DOI: 10.13189/aeb.2020.080602.

Copyright $\odot 2020$ by authors, all rights reserved. Authors agree that this article remains permanently open access under the terms of the Creative Commons Attribution License 4.0 International License

\begin{abstract}
In this paper, I analyze China's economic growth and financial development after 1978's reform and opening-up, and verify whether convergence hypothesis and financial deepening hypothesis exist by using the provincial data from 1978 to 2014. The main contribution is that I examine regional disparities in China's economic growth and financial development by period, consider the effects of Deng Xiaoping's Southern Tour Talks in 1992 and China's accession to the WTO in 2001 on regional economic growth and financial development. The empirical analyses clarify that the convergence hypothesis is valid for the whole sample period of 1978-2014 and the sub-period 2002-2014. Analyses of economic convergence reveal that the poorer provinces have tended to show higher rates of economic growth than the richer provinces during the period 1978-2014, particularly after China's accession to the WTO in 2001. On the other hand, the financial deepening hypothesis only appears to be valid to the whole period of 1978-2014, which means that the provinces with larger financial sectors have tended to show higher rates of economic growth than the provinces with smaller financial sectors over the long term, but this was not valid for any of the sub-periods considered (1978-1991, 1992-2001, and 2002-2014) due to reforms of SOEs, diversification of corporate financing methods, and changes in China's economic and financial situation, which prevented bank loans from making a positive impact on economic growth during any one of the sub-periods.
\end{abstract}

Keywords Chinese Economy, Economic Growth, Financial Development, Economic Convergence, Financial Deepening

\section{Introduction}

After launching the reform and opening-up policies in 1978, China became actively involved in trade and foreign direct investment (FDI) and achieved significant economic development. After joining the World Trade Organization (WTO) in December 2001, China became integrated into the global economy and achieved remarkable financial development. The progress of its economic growth in recent years has not been entirely smooth, however. China's rapid rate of economic growth has created economic gaps, and economic disequilibrium has become an issue of some concern in the country.

The neoclassical growth model-known as the SolowSwan growth model or the exogenous growth model - suggests that an economy with a lower per capita income tends to grow at a higher rate than an economy with a higher per capita income, so per capita income converges in every form of economy. ${ }^{1}$ The model seeks to examine long-term economic growth by analyzing productivity, capital accumulation, population increase, and technological progress. The neoclassical growth model suggests that the per capita income of a poorer economy tends to grow at a faster rate than that of a richer

1 There are two versions of convergence: absolute and conditional convergence. In this paper, I only examine whether absolute convergence holds for China. Absolute convergence considers groups that have access to the same technology, the same population growth rate and the same savings propensity, and only differ in terms of their initial capital-labor ratio [1]. 
economy. According to this principle, all economies eventually converge in terms of per capita income. Poorer countries can imitate production methods, technologies, and machines used in developed countries and, thus, have the potential to grow faster than developed countries. In recent years, many empirical analyses have been conducted on the convergence hypothesis of the SolowSwan growth model. Regarding economic growth and convergence, [2], [3], [4] analyze the world economy; [5] analyzes the US economy, and [6] analyzes the economies of the US, Japan, and five EU countries. [7] examines convergence among sixteen industrialized countries, focusing on the period from 1870 to 1979. [2], [5] analyze the speed of convergence using cross-sectional data. [8], [9] analyze the speed of convergence using panel data. There are currently still large economic gaps between developed and developing countries, which casts some doubt on the neoclassical growth model.

The convergence of China's economic growth has also been examined using the neoclassical growth model by, for example, [10], [11], [12], [13], [14], [15]. Based on the Solow growth model, [10] analyzes China's economic growth by using cross-sectional and panel data. According to their analyses, conditional convergence of per capita production was observed among the provinces from 1978 to 1993 . The convergence was conditional on employment, investments in human capital, foreign direct investments, and coastal locations. [11] assumes the economic convergence model of the neoclassical growth theory and analyzes economic convergences using data on economic growth and population in each Chinese province from 1980 to 2009. Their analyses indicate that the eastern region shows a higher tendency towards convergence and that the speed of convergence drops in many provinces. Following the Solow growth model, [12] examines the tendency toward economic convergence among China's major provinces during the pre-reform period from 1953 to 1977 and the post-reform period from 1978 to 1997 . It became evident that economic growth in China diverged because the rate of technological progress varied between coastal and inland provinces. Furthermore, [13] uses metric entropy measures to investigate economic convergence in China. They found that convergence existed for both the pre- and post-reform periods and that economic growth was more convergent during the post-reform period. [14] uses the GMM estimator to analyze conditional convergence in China. According to these analyses, conditional convergence could be found during the period 1995-2009 and especially during the period of 2004-2009, when China's economic growth converged more quickly. [15] analyzes economic convergence in China, and verify that convergence has been rapid in the manufacturing sector since the end of the 1990s. [16], [17] analyze the convergence of Chinese economic growth through comparisons with other countries [1].
The relationship between economic growth and financial development has drawn much attention from economists and policy-makers. Prior research on the relationship between economic growth and financial development has been varied. [18] notes that the growth of the financial sector enhances capital productivity and plays an important role in economic development. [19] and [20] suggest financial theories for developing countries, with [19] noting that a rise of the real interest rate promotes economic growth, and [20] insisting that financial intermediation promotes economic development in developing countries. [21] argues the classical dichotomy and suggest an analysis framework to verify the long-term neutrality of money, according to which the dichotomy still exists, especially regarding the role of financial intermediary organizations in promoting sustainable economic growth over the long term. [22] suggests that there is a strong correlation between the development of the financial sector and the economic growth rate, while [23] also notes that the development of the financial sector contributes greatly to economic growth, giving rise to the research field of "financial deepening". [24] points out that asymmetry of information exists between lenders and borrowers and suggest that lending affects the real economy. [25] reviews a lot of literature on the financial system in economic growth, and [26] suggests that the rise of liquidity for stock markets plays an important role in economic growth. [27] suggests that the development of the financial sector and legal systems play important roles in long-term economic growth. [28] indicates that the banking department and the market section affect economic development. [29] shows credit markets and stock markets affect economic growth in the long run. [30] suggests that, although financial development can affect economic growth, excess financial development can have adverse effects. [31] shows that a strong relationship between financial development and economic growth can only be found during the early stages of economic development. Moreover, the more the financial sector develops in developing countries, the more economic growth can be realized. [32] reveals that development in the industrial and agricultural sectors affect development in the banking sector positively and negatively, respectively. If a country's banking sector has developed to a high level, this can negatively affect development in the agricultural sector.

Previous research on the financial development of and economic growth in China can be found in [33], [34], [35], [36] and others. [33] uses provincial-level data from the period 1991-2005 to analyze the relationship between bank fund reallocation and regional economic growth in China. Their analyses reveal a positive relationship between bank deposits at the four state-owned commercial banks and China's regional economic growth, while there was no relationship between bank loans and economic growth. They also find that economic growth affects 
financial development in China, and financial development also positively affects economic growth alongside economic reforms. [34] finds that financial development has a positive effect on economic growth by analyzing data from 286 Chinese cities during the period 2001-2006. Using two-stage least squares regressions and provincial panel data from 2001 to 2013, [35] shows that bank concentration had a negative effect on economic growth. [36] uses a threshold model and cross-provincial data covering the period of $1978-2010$ to analyze the relationship between financial development and economic growth in China. They reveal that financial development positively affects the economic growth of high-income provinces, but in poor provinces, where state-owned companies play an important role in industrial output, the effect is negative and great.

By considering China's economic growth after the implementation of the reform and opening-up policies, [1] analyses the problem of economic disparity. China's economic growth is clarified from the viewpoints of domestic investment, exports and foreign direct investment, and changes to the structure of industry. The analyses also reveal that the level of economic growth is relatively high in the eastern provinces, while in the central and, especially, the western provinces, the level of economic growth remains low. [37] examines China's economic growth and financial development by using the provincial data from during the period of 1978 to 2012, and the analysis results show that the hypothesis doesn't exist in any period. The China's economic growth rate had been maintained to $7 \%$ until 2014. Since then, the era of rapid economic growth (with an annual growth rate greater than 7\%) has ended for China, which means China's economy has entered a "new normal" of a medium-to-high speed growth. It is necessary to analyze the China's economic growth and financial development during the period of 1978 to 2014.

This paper analyses both China's economic growth and its financial development, and classifies the relationship between the two. The main contribution of this paper is that it not only considers China's economic growth and financial development after the implementation of the reform and opening-up policies in 1978, but also does so through the use of provincial panel data from 1978 to 2014, with particular attention to whether they follow the convergence and financial deepening hypotheses. This paper also considers the effects of Deng Xiaoping's Southern Tour Talks in $1992^{2}$ and China's accession to the WTO in 2001 on regional economic growth and financial development by examining the relevance of the two hypotheses during three sub-periods: 1978-1991, 1992-2001, and 2002-2014.

2 The Southern Tour Talks refer to a sequence of statements made by Deng Xiaoping during tours to Wuhan, Shenzhen, Zhuhai, Shanghai and other places in 1992.
This paper first introduces the background of China's economic growth and financial development after reform and opening-up. Then, empirical analyses of China's economic growth and financial development are conducted following the convergence hypothesis to verify whether poorer areas tend to grow faster than richer areas, and following the financial deepening hypothesis, to verify whether provinces with larger financial sectors tend to grow faster than those with smaller financial sectors. Finally, the implications for China's economic growth and financial development are derived based on the results of these empirical analyses.

\section{China's Economic Growth and Financial Development}

In December 1978, the Third Plenary Session of the 11th Central Committee of the Chinese Communist Party announced that China would implement the economic reforms and opening-up policies. ${ }^{3}$ The country thereafter gradually departs from a centrally planned economy, moving towards a market economy and achieving remarkable economic growth. Since the pursuit of reform and opening-up, China has achieved notable economic development and maintained a high level of sustainable growth. In 1978, China's nominal GDP was 364.5 billion yuan, which increased to 63.6 trillion yuan in 2014. In addition, real per capita GDP was 378.7 yuan in 1978 and rose to 7523.7 yuan in 2014 , approximately twenty times the earlier measure. ${ }^{4}$ Currently, China is the world's second largest economic power after the United States and the world's largest exporter and importer of goods and services. This section examines China's economic growth in terms of its economic development after 1978's reform and opening-up and the transformation of the industrial structure.

Figure 1 illustrates China's real economic growth rate, and it is evident that 1984 , with $15.2 \%$ growth, marked the highest growth, and 1990, with $3.8 \%$, marked the lowest growth rate in the past 37 years. ${ }^{5}$ Table 1 presents the statistics for China's real economic growth rate, ${ }^{6}$ showing that the average rate of growth was $9.8 \%$ from 1978 to 2014 , with a standard deviation of $2.7 \%$. It is clear from these data that China has grown rapidly during this period.

3 Economic reforms include the decentralization of economic authority, introduction of market competition, and acknowledgement of non-state ownership. Opening-up policies imply the expansion of trade and the introduction of foreign direct investment.

4 The benchmark year for real values is 1978 . This also holds for related descriptions in other parts of this paper.

5 Refer to [38].

6 The calculations are based on [38]. 


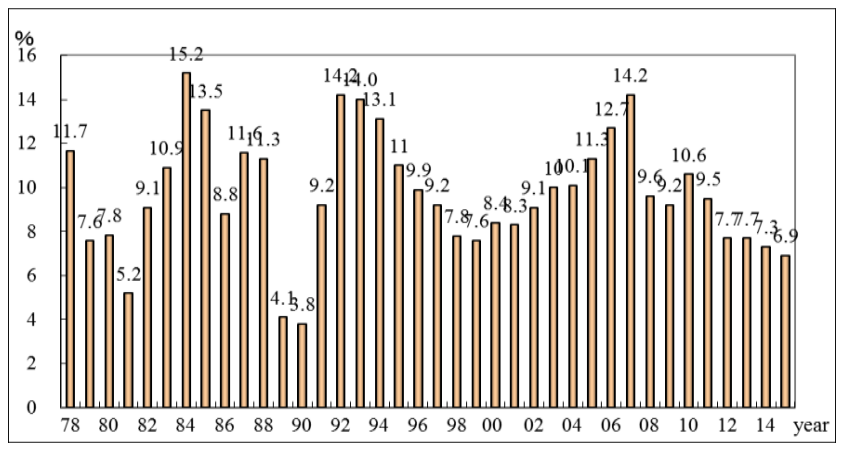

Figure 1. Real Economic Growth Rate

Table 1. Basic Statistics for the Economic Growth Rate (1978-2014, \%)

\begin{tabular}{|c|c|}
\hline Mean & 9.8 \\
\hline Median & 9.5 \\
\hline Standard deviation & 2.7 \\
\hline Kurtosis & 2.8 \\
\hline Skewness & -0.05 \\
\hline Minimum & 3.8 \\
\hline Maximum & 15.2 \\
\hline Samples & 37 \\
\hline
\end{tabular}

China's economy has grown, so has its financial sector. According to [39], at the end of 2015, China's banking sector included 4,262 incorporated banking institutions with 3.8 million employees. These include three policy banks, ${ }^{7}$ five large commercial banks, ${ }^{8} 12$ joint stock commercial banks, ${ }^{9} 133$ city commercial banks, five private banks, 859 rural commercial banks, 71 rural cooperative banks, 1,373 rural credit cooperatives (RCCs), one postal savings bank, four asset management companies, 40 locally incorporated foreign banking institutions, 68 trust companies, 224 finance companies of corporate groups, 47 financial leasing companies, five money brokerage firms, 25 auto financing companies, 12 consumer finance companies, 1,311 village or township banks, 14 lending companies, and 48 rural mutual cooperatives.

Using the Marshallian $k$ (M2/GDP) can help show the relationship between economic growth and financial development. Figure 2 represents a time series transition of Marshallian $k$ from 1978 to 2014 in China [38]. ${ }^{10}$

From Figure 2, it is clear that China's Marshallian $k$ has

7 The three policy banks are the China Development Bank, Export-Import Bank of China, and Agricultural Development Bank of China.

8 The five large commercial banks are the Industrial and Commercial Bank of China, Agricultural Bank of China, Bank of China, China Construction Bank, and Bank of Communications.

9 The twelve joint-stock commercial banks are the China CITIC Bank, China Everbright Bank, Huaxia Bank, China Guangfa Bank, Ping An Bank, China Merchants Bank, Shanghai Pudong Development Bank, Industrial Bank, China Minsheng Banking Corporation, Evergrowing Bank, China Zheshang Bank and Bohai bank.

10 The calculations are based on [38]. been rising, going up from 0.32 in 1978 , to 0.67 in 1988 , 1.23 in 1998, 1.49 in 2008, and reaching 1.91 in 2014. This indicates that money supply could have expanded faster than the real economy in China. In reality, however, regional governments controlled the investment decisions of state-owned companies, and the banks basically continued to furnish financing in accordance with those intentions. Government-run commercial banks prudently strengthened their risk management, as an increase in the number of non-performing loans became a problem. As a result of these interventions, money supply has not created sufficient demand, particularly as loans are not easily provided to small and medium-sized enterprises.

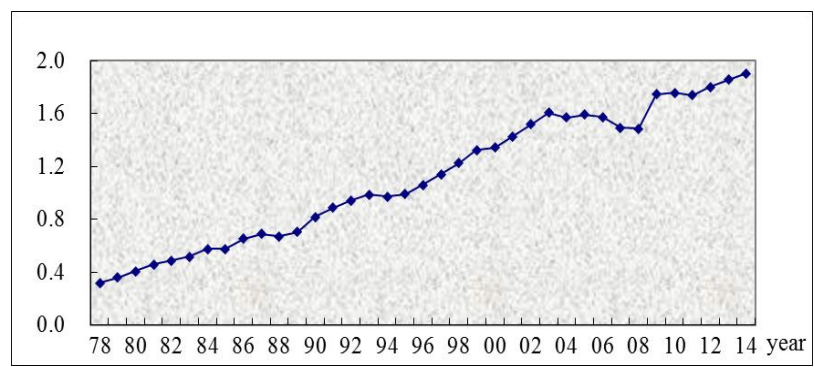

Figure 2. Marshallian $k$ (M2/GDP)

Figure 3 shows the economic growth and financial development of each province during the period 19782014. ${ }^{11}$ The horizontal axis represents real per capita GDP, and the vertical axis represents real per capita loans, shown in yuan.

As shown in the figure, the differences between provinces can be very large. Shanghai, for example, has both the highest level of real per capita GDP (7420.8 yuan) and the highest level of real per capita loan (12630.8 yuan). Beijing has both the second highest level of real per capita GDP (6419.9 yuan) and real per capita loan (12327.3 yuan). Tianjin, meanwhile, has the third highest level of real per capita GDP (5581.6 yuan) and real per capita loan (7511.7 yuan). Zhejiang and Jiangsu provinces also have high levels of real per capita GDP and real per capita loan.

Guizhou, on the other hand, has both the lowest levels of real per capita GDP (1036.2 yuan) and real per capita loan (1135.3 yuan). Tibet has the fourth lowest level of real per capita GDP (1487.3 yuan) and the second lowest level of real per capita loan (1201.2 yuan).

11 Refer to [38], [40]. 


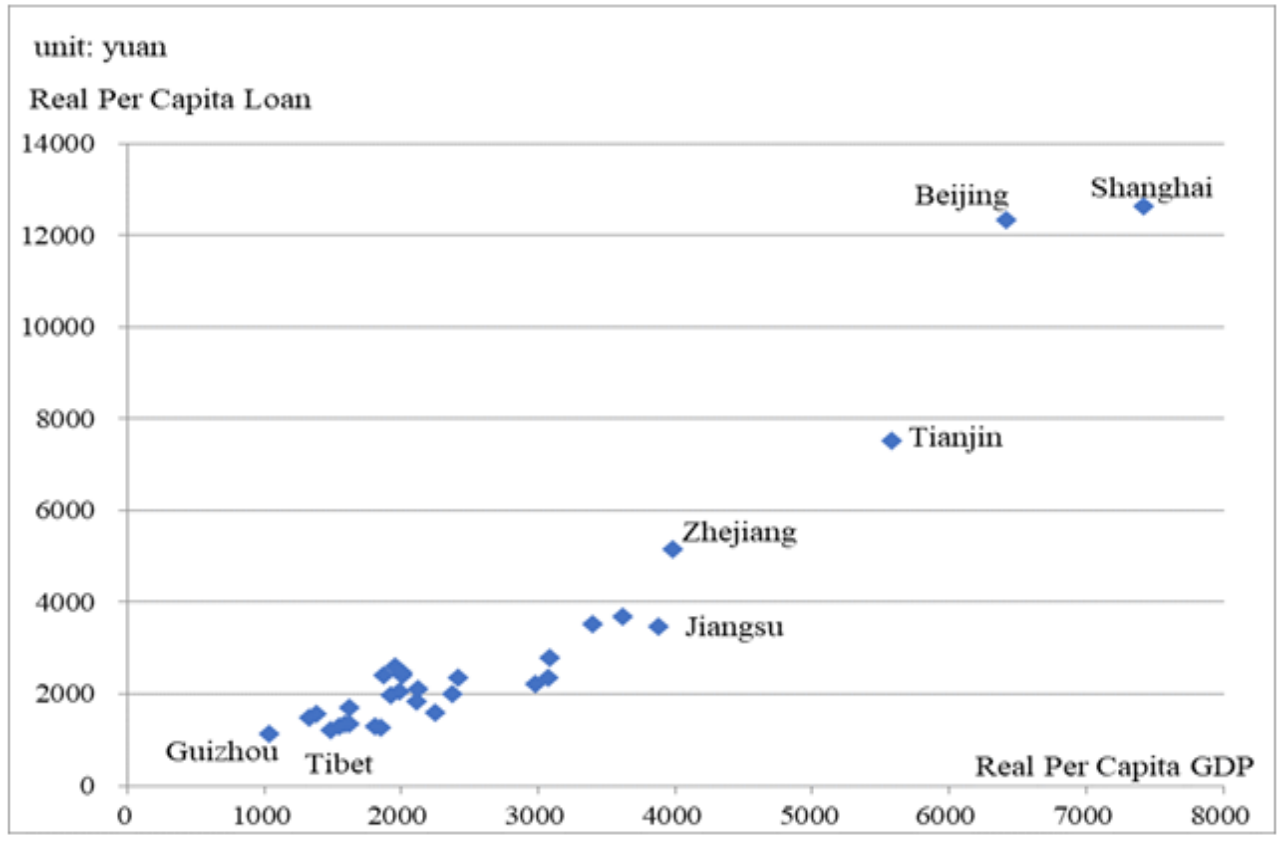

Figure 3. Provincial Economic Growth and Financial Development (1978-2014)

\section{Empirical Analyses of Convergence and Financial Deepening Hypotheses}

\subsection{Data}

This section conducts empirical analyses using data from the thirty-one provincial-level divisions (i.e., twenty-two provinces, four municipalities and five autonomous regions) to verify the following two hypotheses [38], [40]: 1) the convergence hypothesis: poorer regions tend to grow faster than richer regions; and 2) the financial deepening hypothesis: regions with larger financial sectors tend to develop more than those with smaller financial sectors. The sample period is from 1978 to 2014 .

This paper uses real per capita GDP from the thirty-one provincial-level divisions during the whole sample period, while real per capita loan from the thirty-one provincial-level divisions is used as the variable of financial development. ${ }^{12}$ Real per capita GDP and real per capita loan can be obtained by dividing the nominal per capita GDP and nominal per capita loan, respectively, by the GDP deflator from the benchmark year (1978). This paper also classifies the thirty-one provincial-level divisions into three regional categories: eastern, central, and western regions. ${ }^{13}$

Table 2 shows the average real per capita GDP, real per capita GDP growth rate, and real per capita loan by province, and Table 3 presents the relevant statistics. ${ }^{14}$ As

12 Bank lending and deposit amounts are the stock data at the end of each year.

13 This paper includes Liaoning, Jilin and Heilongjiang provinces, which are located in the northeast of China, in the eastern region.

14 The calculations are based on [38], [40]. these tables indicate, China's economic growth is characterized by geographical imbalance. There are economic gaps between the eastern coastal region, including the Shanghai and Beijing municipalities, and the western inland region, such as Guizhou and Gansu provinces. The average real per capita GDP is usually high in the eastern region and low in the western region. For example, in Shanghai municipality, the richest city in the eastern region, the average real per capita GDP is 7420.8 yuan, approximately seven times as large as that of Guizhou, the poorest province in the western region. The yearly average values of real per capita GDP also increased at an astonishing rate of $9.6 \%$ over the past thirty-seven years. The eastern province of Jiangsu has the highest growth rate for real per capita GDP (11.8\%), whereas Beijing municipality, the capital of China, has the lowest rate of $7.6 \%$. Rates of growth are also high elsewhere; in the eastern region, Zhejiang province has a rate of $11.6 \%$ and Fujian province has a rate of $11.4 \%$, and the Inner Mongolia autonomous region in the central region has a rate of $11.2 \%$. Shandong, Guangdong and Hainan provinces in the eastern region, Henan and Hubei provinces in the central region, and Chongqing municipality and Sichuan province in the western region also have economic growth rates over $10 \%$. Average real per capita loan tends to be relatively large in the eastern direct-controlled municipalities, such as Shanghai, Beijing and Tianjin, and smaller in the central and western regions. For example, the real per capita loan in Shanghai city, which is the nation's largest, is approximately thirteen times that of Tibet, which is the smallest. 
Table 2. Averages from Provincial-level Data (1978-2014)

\begin{tabular}{|c|c|c|c|c|c|}
\hline Number & Province & $\begin{array}{c}\text { Real per capita GDP } \\
\text { (yuan) }\end{array}$ & $\begin{array}{l}\text { Real per capita GDP } \\
\text { growth rate }(\%)\end{array}$ & $\begin{array}{l}\text { Real per capita } \\
\text { loan (yuan) }\end{array}$ & Region \\
\hline 1 & Beijing & 6419.9 & 7.6 & 12327.3 & East \\
\hline 2 & Tianjin & 5581.6 & 9.6 & 7511.7 & East \\
\hline 3 & Hebei & 2249.2 & 9.5 & 1579.2 & Central \\
\hline 4 & Shanxi & 1984.2 & 8.9 & 2056.0 & Central \\
\hline 5 & InnerMongolia & 2983.8 & 11.2 & 2204.9 & Central \\
\hline 6 & Liaoning & 3400.7 & 9.1 & 3529.4 & East \\
\hline 7 & Jilin & 2411.3 & 9.8 & 2346.2 & East \\
\hline 8 & Heilongjiang & 2368.0 & 8.1 & 2000.2 & East \\
\hline 9 & Shanghai & 7420.8 & 8.1 & 12630.8 & East \\
\hline 10 & Jiangsu & 3879.7 & 11.8 & 3463.6 & East \\
\hline 11 & Zhejiang & 3977.9 & 11.6 & 5150.9 & East \\
\hline 12 & Anhui & 1592.1 & 9.8 & 1357.9 & Central \\
\hline 13 & Fujian & 3083.7 & 11.4 & 2799.0 & East \\
\hline 14 & Jiangxi & 1622.4 & 9.3 & 1341.0 & Central \\
\hline 15 & Shandong & 3068.6 & 10.9 & 2352.4 & East \\
\hline 16 & Henan & 1804.0 & 10.2 & 1298.5 & Central \\
\hline 17 & Hubei & 2107.6 & 10.1 & 1822.5 & Central \\
\hline 18 & Hunan & 1847.7 & 9.2 & 1270.7 & Central \\
\hline 19 & Guangdong & 3614.1 & 10.5 & 3679.9 & East \\
\hline 20 & Guangxi & 1552.2 & 8.9 & 1293.5 & West \\
\hline 21 & Hainan & 2003.5 & 10.4 & 2461.6 & East \\
\hline 22 & Chongqing & 2003.8 & 10.6 & 2394.6 & West \\
\hline 23 & Sichuan & 1626.0 & 10.2 & 1687.4 & West \\
\hline 24 & Guizhou & 1036.2 & 9.3 & 1135.3 & West \\
\hline 25 & Yunnan & 1380.5 & 9.1 & 1554.1 & West \\
\hline 26 & Tibet & 1487.3 & 8.9 & 1201.2 & West \\
\hline 27 & Shanxi & 1925.4 & 10.0 & 1970.6 & Central \\
\hline 28 & Gansu & 1324.8 & 8.9 & 1483.2 & West \\
\hline 29 & Qinghai & 1871.3 & 8.5 & 2413.0 & West \\
\hline 30 & Ningxia & 1950.6 & 8.0 & 2605.3 & West \\
\hline 31 & Xinjiang & 2125.5 & 8.6 & 2114.1 & West \\
\hline
\end{tabular}

Table 3. Basic Statistics of Data in Table $2(\mathrm{~N}=31)$

\begin{tabular}{|c|c|c|c|}
\hline & Real per capita GDP (yuan) & Real per capita GDP growth rate (\%) & Real per capita loan (yuan) \\
\hline Mean & 2635.6 & 9.6 & 3001.2 \\
\hline Median & 2003.8 & 9.5 & 2114.1 \\
\hline Standard deviation & 1502 & 1.1 & 2843.6 \\
\hline Kurtosis & 5.6 & 2.3 & 2.8 \\
\hline Skewness & 1.8 & 0.2 & 1135.3 \\
\hline Minimum & 1036.2 & 7.6 & 12630.8 \\
\hline Maximum & 7420.8 & 11.8 & 31 \\
\hline Samples & 31 & 31 & \\
\hline
\end{tabular}


As is clear from the data, there are currently significant economic disparities between China's eastern coastal areas (e.g., Shanghai and Guangdong) and inland western areas such as Gansu Province and Tibet. After 1978's reform and opening-up, economic development clustered in coastal areas because these were most accessible to investment from foreign-affiliated companies, and migrant workers from inland areas were inexpensive and provided the abundant labor force necessary for economic development. As a result of this intensive flow of humans, goods, and money, the coastal areas accumulated industrial structures, allowing the development of a market economy and greatly contributing to the development of the Chinese economy as the factory of the world. Poor transportation and inefficient infrastructure have contributed to delaying the economic development of inland regions [1].

\subsection{Empirical Analyses}

This section conducts empirical analyses to verify the following two hypotheses:

H1. Convergence: Poorer regions tend to grow faster than richer regions;

H2. Financial deepening: Regions with larger financial sectors tend to develop more than those with smaller financial sectors.

By referring to [2], [3], [5], [7], [41], [42], [43], the calculation equation is explained in the following manner. ${ }^{15}$

$$
\begin{gathered}
\operatorname{In}\left[(Y / P)_{i, n}\right]-\operatorname{In}\left[(Y / P)_{i, m}\right]=a+b \operatorname{In}\left[(Y / P)_{i, m}\right]+ \\
\operatorname{cIn}\left[(F / P)_{i, m}\right]+\varepsilon_{i} \quad i=1,2, \ldots, 31
\end{gathered}
$$

Here, $\operatorname{In}(Y / P)$ indicates the logarithm of real per capita GDP; $i$ represents the thirty-one provincial-level divisions; and $\varepsilon$ represents an error term. This section only considers the data at the time of the initial $(m)$ and final $(n)$ points of the calculation period. That is, $\operatorname{In}\left[(Y / P)_{i, m}\right]$ indicates the logarithm of real per capita GDP of $i$ at $m$, the initial point of economic growth, and $\operatorname{In}\left[(F / P)_{i, m}\right]$ indicates the logarithm of real per capita loan of $i$ at $m$. On the left side, $\operatorname{In}\left[(Y / P)_{i, n}\right]-\operatorname{In}\left[(Y / P)_{i, m}\right]$ indicates the real per capita GDP growth rate of $i$, during the period $n-m$.

By calculating the coefficient $b$ in the equation, we can examine whether gaps converge or disperse. If there is convergence, $b$ has a negative value, and $i$ with a higher value of real per capita GDP at the initial point has a lower rate of economic growth at the final point, which implies that economic gaps contract [3]. By calculating the coefficient $c$ in the equation, we can examine the financial deepening hypothesis. If financial deepening exists, $c$ has a positive value, and $i$ with a larger value of real per capita loan at the initial point has a higher rate of

15 This section just examines whether convergence can be observed and does not consider convergence speed. economic growth at the final point, which implies a large degree of economic development.

The equation is calculated in the following manner. First, to examine whether the convergence and financial deepening hypotheses are valid during the period from the beginning of reform and opening-up to the present, calculations for the whole sample period are conducted by setting 1978 as the initial point of the calculation period and 2014 as the final point. Next, as mentioned above, given that Deng Xiaoping's Southern Tour Talks in January-February 1992 and China's accession to the WTO in December 2001 both had an enormous impact on the Chinese economy, this paper conducts calculations of the equation by dividing the sample period into three sub-periods of 1978-1991, 1992-2001 and 2002-2014 to examine the accuracy of the hypotheses during these periods.

\subsection{Results and Discussion}

Table 4 presents the results of the calculations for the whole period from 1978 to 2014. For this period, the coefficient $b$ is -0.9469 and the $t$ value is -3.8869 , which imply that the results are significantly negative, at the $1 \%$ significance level. The results of calculations for the whole period from 1978 to 2014 show that the convergence of economic growth progressed and economic gaps narrowed. When considering the whole period, the coefficient $c$ is 0.4055 and the $t$-value is 1.9824, which imply that the results are significantly positive at the $10 \%$ significance level. These results suggest that the financial deepening hypothesis is relevant for the period from 1978 to 2014 .

Table 4. Convergence and Financial Deepening Estimates (19782014)

\begin{tabular}{|c|c|c|c|c|}
\hline Variable & Coefficient & $\begin{array}{c}\text { Standard } \\
\text { error }\end{array}$ & $t$-statistic & Probability \\
\hline$a$ & 6.4870 & 0.5973 & 10.8612 & 0.0000 \\
\hline$b$ & -0.9469 & 0.2436 & -3.8869 & 0.0006 \\
\hline$c$ & 0.4055 & 0.2046 & 1.9824 & 0.0573 \\
\hline
\end{tabular}

Table 5 shows the results of the calculations for the three sub-periods of 1978-1991, 1992-2001, and 2002 2014.

The estimated results of the convergence hypothesis for the three sub-periods are as follows. For the first sub-period, 1978-1991, the coefficient $b$ is -0.2861 and the $t$-value is -1.5382 , which means that the results are not significantly negative at the $10 \%$ significance level. For the second sub-period, 1992-2001, the coefficient $b$ is 0.3587 , and the $t$-value is 3.0269 , which means that the results are significantly positive at the $1 \%$ significance level. For the third sub-period, 2002-2014, the coefficient $b$ is -0.3173 and the $t$-value is -2.0593 , which implies that the results are significantly negative at the $5 \%$ significance level. This shows that in the sub-period 
2002-2014, the convergence of economic growth has progressed and economic gaps have narrowed, while in the sub-period 1992-2001, economic gaps expanded.

The estimation results of the financial deepening hypothesis for the three sub-periods are as follows. For the first sub-period, 1978-1991, the coefficient $c$ is 0.0425 , and the $t$-value is 0.2720 , which means that the results are not significantly positive at the $10 \%$ significance level. For the second sub-period, 1992-2001, the coefficient $c$ is -0.1971 and the $t$-value is -2.0738 , which means that the results are also not significantly positive at the $10 \%$ significance level. For the third sub-period, 2002-2014, the coefficient $c$ is -0.0444 and the $t$ value is -0.3570 , which implies that the results are not significant at the $10 \%$ significance level. The results show that the financial deepening hypothesis is not supported for each of the sub-periods of 1978-1991, 1992-2001, and 2002-2014.

As for the estimation results of the convergence hypothesis, for the whole period of 1978-2014, the less developed and poorer province at the initial point (1978) showed a higher rate of growth at the final point (2014), supporting the convergence hypothesis. In terms of sub-periods, for the first sub-period (1978-1991) convergence of economic growth could not be proved, while economic gaps expanded during the second sub-period (1992-2001). However, for the third sub-period (2002-2014), economic gaps have diminished and the convergence hypothesis appears to be valid.

There are several reasons why economic inequality decreased during the period 2002-2014. After launching the reform and opening-up policies in 1978, China achieved significant economic development and became actively involved in trade and foreign direct investment. Foreign-affiliated companies branched out into China's eastern coastal areas and formed the nucleus of China's export-driven economic growth. Migrant workers from inland areas provided a low-cost and abundant workforce that was essential for economic development. An intensive flow of human and material resources and capital triggered the penetration of the free market economy into the coastal areas, as well as the formation of industrial agglomerations, which greatly helped develop the Chinese economy as "the factory of the world". This economic development caused a gradual saturation of coastal markets, however, and excessive capital investment and a surge in real estate prices - as well as a rise in personnel costs - began to cast a shadow over corporate performance. Due to the government's initiatives for large-scale development in the western region, infrastructure began to develop in the inland areas. Since the 2000s - especially after the mid-2000s - foreign-affiliated companies and private enterprises have transferred their factories from coastal to inland areas in search of a lower-cost workforce and markets with a stronger demand. Preferential tax measures and subsidies by local governments inland also accelerated the inflow of production facilities and human resources into these regions. As a result, coastal areas are currently facing sluggish growth, while inland areas are maintaining high-level economic growth - supporting the convergence hypothesis [1].

Table 5. Convergence and Financial Deepening Estimates by Sub-period

\begin{tabular}{|c|c|c|c|c|}
\hline \multicolumn{5}{|c|}{ Sample: 1978-1991 } \\
\hline Variable & Coefficient & Standard error & $t$-statistic & Probability \\
\hline$a$ & 2.3968 & 0.4560 & 5.2556 & 0.0000 \\
\hline$b$ & -0.2861 & 0.1860 & -1.5382 & 0.1352 \\
\hline$c$ & 0.0425 & 0.1562 & 0.2720 & 0.7876 \\
\hline \multicolumn{5}{|c|}{ Sample: 1992-2001 } \\
\hline Variable & Coefficient & Standard error & $t$-statistic & Probability \\
\hline$a$ & -0.3982 & 0.3369 & -1.1821 & 0.2471 \\
\hline$b$ & 0.3587 & 0.1185 & 3.0269 & 0.0053 \\
\hline$c$ & -0.1971 & 0.0950 & -2.0738 & 0.0474 \\
\hline \multicolumn{5}{|c|}{ Sample: 2002-2014 } \\
\hline Variable & Coefficient & Standard error & $t$-statistic & Probability \\
\hline$a$ & 3.9704 & 0.4490 & 8.8421 & 0.0000 \\
\hline$b$ & -0.3173 & 0.1541 & -2.0593 & 0.0489 \\
\hline$c$ & -0.0444 & 0.1244 & -0.3570 & 0.7238 \\
\hline
\end{tabular}


Different from the financial deepening estimation results of [37], that it, the hypothesis doesn't exist in any period, in this paper, for the whole period of 1978-2014, the province with larger financial sectors at the initial point (1978) showed a higher rate of growth at the final point (2014), proving the financial deepening hypothesis valid in the long run. After the pursuit of reform and opening-up, development of the financial sectors greatly contributed to China's economic growth. In the long term, state-owned enterprises have accounted for a large proportion of industrial production, raised funds from state-owned commercial banks, and contributed to China's economic development. However, for each sub-period of 1978-1991, 1992-2001, and 2002-2014, the financial deepening hypothesis was not relevant.

By 1978, state-owned enterprises (SOEs) operated based on state production plans and price controls, and produced nearly three-quarters of the country's industrial production according to centrally planned output targets. Following reform and opening-up, a system of economic responsibility was introduced into the management of SOEs from 1981, and management autonomy spread. More reforms were implemented in 1993, recognizing other forms of ownership, so the number of private enterprises increased. As a result, only large-scale SOEs remained, which dominated many key industries and undertook special projects or manufacturing, such as national defense and railways. Other small- and medium-sized enterprises were actively privatized. Since the 2000s - especially when economic stimulus measures were applied after the collapse of Lehman Brothers - many financial funds were directed to large SOEs, so there has been a rise in the state-owned sector and shrinkage of the private sector in some areas.

At the beginning of reform and opening-up, SOEs raised funds from state-owned commercial banks. State-owned commercial banks excessively pursued the expansion of the loan and deposit scales without thinking about profitability or fundamental efficiency; this hindered competition between banks and lowered the efficiency of fund allocation. It was also difficult to completely eliminate adhesion with local governments. In response to this situation, financial system reforms were implemented, so that the numbers not only of state-owned commercial banks but also of other forms of financial institutions have been increasing. Following the establishment of the Shanghai Stock Exchange in December 1990 and the Shenzhen Stock Exchange in January 1991, SOEs could raise funds not only from domestic banks but also from mainland stock markets. With the return of Hong Kong to Chinese governance in 1997, SOEs have been listed on the Hong Kong market and were afterwards also listed on overseas markets such as the New York Stock Exchange; this has diversified the fund-raising methods available to SOEs. China's accession to the WTO at the end of 2001 brought about a breakthrough in the nation's banking industry. The four largest state-owned commercial banks in China rank in the top ten in the world with market capitalization and have recently made huge loans - mainly to SOEs-for infrastructure construction projects.

Due to reforms of SOEs, diversification of corporate financing methods, and changes in China's economic and financial situation - among other factors - the financial deepening hypothesis does not appear to be valid for the sub-periods 1978-1991, 1992-2001, and 2002-2014.

\section{Conclusions}

This paper considers China's economic growth and financial development after 1978's reform and opening-up. Using provincial-level data over the period of 1978-2014, this paper conducts empirical analyses of China's economic growth and financial development, including period-by-period analyses, to examine whether the convergence and financial deepening hypotheses were valid for China during this period.

The empirical analyses clarify that the convergence hypothesis is valid for the whole sample period of 19782014 and the sub-period 2002-2014. In China, the level of economic growth was relatively high in the eastern provinces, while in the central and, especially, the western regions, the level of economic growth remained low. Analyses of economic convergence reveal that the poorer provinces have tended to show higher rates of economic growth than the richer provinces during the period 19782014, particularly after China's accession to the WTO in 2001.

The financial deepening hypothesis only appears to be valid to the whole period of 1978-2014, which means that the provinces with larger financial sectors have tended to show higher rates of economic growth than the provinces with smaller financial sectors over the long term, but this was not valid for any of the sub-periods considered (1978-1991, 1992-2001, and 2002-2014) due to reforms of SOEs, diversification of corporate financing methods, and changes in China's economic and financial situation, which prevented bank loans from making a positive impact on economic growth during any one of the sub-periods.

Recently, the Chinese economy has slowed down. Personal consumption slumped, while unemployment surged. Cash flows have also worsened for private companies. The government put the brakes on excessive capital and real estate investment. Sluggish foreign demand caused by US-China trade friction has also slowed China's economy in recent years, along with a decline in capital investment in the manufacturing sector, which had been expanding rapidly. The Chinese economy has met a turning point. The slowing pace of Chinese economic growth underscores the country's need to transition from an investment- and export-led growth model to a sustainable domestic consumption-led growth 
model. The focus is to seek growth through economic transformation, optimizing industrial structure, improving the environment and enhancing quality and efficiency, and to shift to an innovation-driven economy. China proposed its vision of a large economic bloc, the "One Belt, One Road" initiative, and established the Chinese-led Asian Infrastructure Investment Bank (AIIB).

Inland areas are becoming increasingly attractive as an investment target and market, and this has led to the expansion of corporate investments in inland regions, whose economic growth is now driving the Chinese economy. Infrastructure development is progressing in these regions, although there is still room for improvement. To reduce regional gaps in economic growth, China needs to expand the middle class and decrease the economic disparity between eastern coastal areas (e.g., Shanghai and Guangdong) and western inland areas, such as Gansu and Guizhou. Government-led supportive measures for inland areas and the strengthening of mechanisms for allocating investments, improvement of inland financial markets, and increasing their efficiency in terms of capital distribution could assist in this effort. Simultaneously, stimulating consumption and promoting education in poorer areas would also be an effective option for facilitating regional economic growth.

In the future, China needs to expand the service industry and hasten the shift to added-value products in coastal areas, while exploiting potential demands and promoting further infrastructure development in inland areas. Through such efforts, China should be able to cope with depressed foreign demand, sluggish domestic demand, and excessive investments, and the Chinese economy would be able to achieve stable and sustainable growth.

Financial development in China has had a positive role in the country's economic growth in the long run, although it has not appeared to affect short-term growth for any of the sub-periods considered. Since China joined the WTO in 2001, the country has become integrated into the global economy and its financial industry has significantly developed. It is easier for SOEs to receive government support compared to private enterprises and, as a result, SOEs are in a relatively advantageous position when raising funds through bank loans and issuing corporate bonds. The formation of a financial system centered on state-owned banks has allowed the government to exercise control over both borrowers and lenders.

As the Chinese economy develops, the growing domestic economy will generate increased new demands for financial services; to satisfy the new demand for such services, the financial sector will have to become larger and more sophisticated. A well-functioning financial sector can promote overall economic efficiency, so it is necessary for the government to encourage both the multiplicity of financial institutions and the diversity of financial instruments. The Chinese government also needs to carry out effective measures-minimizing its intervention in financial systems and strengthening financial integration and the status of financial institutions - to reinforce the relationship between financial development and long-term economic growth, to ensure that economic growth is sustainable.

The issue of debt has recently become a matter of concern in China; SOEs account for much of the corporate debt, as they are an important player in a wide range of industries. The debt scale is enormous, and there is a strong possibility that the risk will increase due to the postponement of a solution to the issue. Reform of the financial system is progressing to restrain debt. However, if the reform is implemented too severely, the number of bad loans held by banks will abruptly increase, causing investment and consumer spending to go down, which will place a downward pressure on the real economy. If bad loans continue to increase, however, it could shake the Chinese economy. Careful implementation of reform policies by the government is necessary to handle the question of debt successfully.

New financial technology has developed at a pace exceeding that of financial system reform. Although the period of high economic growth has ended, the demand for funds for infrastructure investment and technical improvement of the manufacturing industry in China is still large, and it is necessary to operate domestic deposits efficiently. Financial services using FinTech have been rapidly growing in recent years. The spread of financial services derived from Internet shopping is significant and has been growing with a momentum exceeding the bank deposit balance. Use of Internet technology has also caused large changes in SME and rural finance. The P2P platform has given private enterprises - previously unable to access bank services-access to financing. China's P2P finance net has become the world's largest in less than ten years, although some of the P2P platforms have faced difficulties, such as unreliable customer review and insolvency. Monitoring and detection of illegal acts remain important issues. To keep the financial system reform in line with the progress of financial technology and economic globalization, it is necessary for the financial authority to clarify rules, establish a disclosure system for illegal acts, and establish fair trials for default on commitments.

Indirect finance dominates direct finance in China, and Chinese companies depend heavily on bank loans. To ease risk concentration in the banking sector, it is important to develop capital markets, which currently lack adequate arbitrament and adjustment functions. China still currently regulates capital dealings, and this regulation is likely to make it impossible to cope adequately with the increasing globalization of capital markets. To ensure its continued economic growth, China needs to make further efforts to develop capital markets, diversify options for corporate capital procurement and investment, and exchange a wide variety of information through risk analysis. Steady and 
deliberate liberalization of capital dealings in China are an essential step for the country's future economic security.

\section{REFERENCES}

[1] Zhang, Y, "China's Economic Growth and Convergence after Economic Reform,” Journal of China Studies, vol. 19, no. 2, pp. 1-17, 2016.

[2] Mankiw, N. G., D. Romer and D. N. Weil, "A Contribution to the Empirics of Economic Growth," Quarterly Journal of Economics, vol. 107, no. 2, pp. 407-437, 1992.

[3] Barro, R. J, "Economic Growth in a Cross Section of Countries," Quarterly Journal of Economics, vol. 106, no. 2, pp. 407-443, 1991.

[4] Sala-i-Martin, X, "The Classical Approach to Convergence Analysis," Economic Journal, vol. 106, no. 437, pp. 1019-1036, 1996a.

[5] Barro, R. J., and X. Sala-i-Martin, "Convergence,” Journal of Political Economy, vol. 100, no. 2, pp. 223-251, 1992.

[6] Sala-i-Martin, X, "Regional cohesion: Evidence and theories of regional growth and convergence," European Economic Review, vol. 40, no. 6, pp. 1325-1352, 1996 b.

[7] Baumol, W. J, "Productivity Growth, Convergence, and Welfare: What the Long-run Data Show," American Economic Review (AER), vol. 76, no. 5, pp. 1072-1085, 1986.

[8] Islam, N, "Growth Empirics: A Panel Data Approach," Quarterly Journal of Economics, vol. 110, no. 4, pp. 1127-1170, 1995.

[9] Lee, K., M. H. Pesaran, and R. Smith, "Growth and Convergence in A Multi-Country Empirical Stochastic Solow Model," Journal of Applied Econometrics, vol. 12, no. 4, pp. 357-392, 1997.

[10] Chen, J., and B. M. Fleisher, "Regional Income Inequality and Economic Growth in China," Journal of Comparative Economics, vol. 22, no. 2, pp. 141-164, 1996.

[11] Pan, L., O. Posch, and M. van der Wel, "Measuring Convergence using Dynamic Equilibrium Models: Evidence from Chinese Provinces," CREATES Research Papers 2012-26, University of Aarhus, 2012.

[12] Weeks, M. and J. Y. Yao, "Provincial Conditional Income Convergence in China, 1953-1997: A Panel Data Approach," Econometric Reviews, vol. 22, no. 1, pp. 59-77, 2003.

[13] Maasoumi, E. and L. Wang, "Economic Reform, Growth and Convergence in China," Econometrics Journal, vol. 11, no. 1, pp. 128-154, 2008.

[14] Bonnefond, C, "GROWTH DYNAMICS AND CONDITIONAL CONVERGENCE AMONG CHINESE PROVINCES: A PANEL DATA INVESTIGATION USING SYSTEM GMM ESTIMATOR," Journal of Economic Development, vol. 39, no. 4, pp. 1-25, 2014.

[15] Lemoine, F., S. Poncet, and D. Ünal, "Spatial rebalancing and industrial convergence in China," China Economic Review, vol. 34, pp. 39-63, 2015.

[16] Brandt, L., D. Ma, and T. G. Rawski, "From Divergence to Convergence: Reevaluating the History behind China's Economic Boom," Journal of Economic Literature, vol. 52, no. 1, pp. 45-123, 2014.

[17] Barro, R. J, "Economic Growth and Convergence, Applied to China," China \& World Economy, vol. 24, no. 5, pp. 5-19, 2016.

[18] Goldsmith, R. W, Financial Structure and Development, Yale University Press, 1969.

[19] McKinnon, R. I, Money and Capital in Economic Development, Brooking Institution, 1973.

[20] Shaw, E. Financial Deepening in Economic Development, Oxford University Press, 1973.

[21] Fisher, M. E. and J. J. Seater, "Long-Run Neutrality and Superneutrality in an ARIMA Framework," American Economic Review, vol. 83, no. 3, pp. 402-415, 1993.

[22] Barro, R. J., and X. Sala-i-Martin, Economic Growth, McGraw-Hill, 1995.

[23] Fry, M.J, Money, Interest and Banking in Economic Development, John Hopkins University Press, 1995.

[24] Stiglitz, J. E. and A. Weiss, "Credit Rationing in Markets with Information," American Economic Review, vol. 71, no. 3, pp. 393-410, 1981.

[25] Levine, R, "Financial Development and Economic Growth: Views and Agenda," Journal of Economic Literature, vol. 35, no. 2, pp. 688-726, 1997.

[26] Levine, R. and S. Zervos, "Stock Markets, Banks and Economic Growth," American Economic Review, vol. 88, no. 3, pp. 537-558, 1998.

[27] Levine, R, "Bank-Based or Market-Based Financial Systems: Which is Better?" Journal of Financial Intermediation, vol. 11, no. 4, pp. 398-428, 2002.

[28] Beck, T. and R. Levine, "Industry Growth and Capital Allocation: Does Having A Market- or Bank-based System Matter?" Journal of Financial Economics, vol.64, no.2, pp.147-180, 2002.

[29] Durusu-Ciftci, Dilek, M. S. Ispir and H. Yetkiner, "Financial development and economic growth: Some theory and more evidence," Journal of Policy Modeling, vol. 39, no. 2, pp. 290-306, 2017.

[30] Law, S. H. and N. Singh, "Does too much finance harm economic growth?” Journal of Banking \& Finance, vol. 41, pp. 36-44, 2014.

[31] Fung, M. K, "Financial development and economic growth: Convergence or divergence?" Journal of International Money and Finance, vol. 28, no. 1, pp. 56-67, 2009.

[32] Tongurai, J. and C. Vithessonthi, "The impact of the banking sector on economic structure and growth," International Review of Financial Analysis, vol. 56, pp. 193-207, 2018.

[33] Chang, P. C., C.x. Jia and Z.c. Wang, "Bank fund reallocation and economic growth: Evidence from China," 
Journal of Banking \& Finance, vol. 34, no. 11, pp. 2753-2766, 2010.

[34] Zhang, J., L. F. Wang and S. S. Wang, "Financial development and economic growth: Recent evidence from China," Journal of Comparative Economics, vol. 40, no. 3, pp. 393-412, 2012.

[35] Diallo, B. and Q. Zhang, "Bank concentration and sectoral growth: Evidence from Chinese provinces," Economics Letters, vol. 154, pp. 77-80, 2017.

[36] Chen, K.C., L.F. Wu and J. Wen, "The relationship between finance and growth in China," Global Finance Journal, vol. 24, no. 1, pp. 1-12, 2013.

[37] Zhang, Y, "Economic Growth and Financial Development in China: An Empirical Analysis Based on Provincial Data," Studies of International Society, vol. 4, pp. 47-59, 2015.

[38] National Bureau of Statistics of China, China Statistical
Yearbook, China Statistics Press.

[39] China Banking and Insurance Regulatory Commission, China Banking Regulatory Commission Annual Report.

[40] National Bureau of Statistics of China, CHINA COMPENDIUM OF STATISTICS 1949-2008, China Statistics Press, 2011.

[41] King, R. G. and R. Levine, "Finance, Entrepreneurship, and Growth: Theory and Evidence," Journal of Monetary Economics, vol. 32, no. 3, pp. 513-542, 1993a.

[42] King, R. G. and R. Levine, "Finance and Growth: Schumpeter Might Be Right," Quarterly Journal of Economics, vol. 108, no. 3, pp. 717-738, 1993b.

[43] Berthelemy, J. C. and A. Varoudakis, "Economic Growth, Convergence Clubs, and the Role of Financial Development," Oxford Economic Papers, vol. 48, no. 2, pp. 300-328, 1996. 